\title{
The endemic and threatened lizard Liolaemus lutzae (Squamata: Liolaemidae): current geographic distribution and areas of occurrence with estimated population densities
}

\author{
Carlos F. D. Rocha 1; Carla da C. Siqueira ${ }^{1,2} \&$ Cristina V. Ariani ${ }^{1}$
}

\begin{abstract}
1 Departamento de Ecologia, Instituto de Biologia Roberto Alcântara Gomes, Universidade do Estado do Rio de Janeiro. Rua São Francisco Xavier 524, Maracanã, 20550-019 Rio de Janeiro, Rio de Janeiro, Brasil. E-mail: cfdrocha@uerj.br ${ }^{2}$ Programa de Pós-Graduação em Ecologia, Instituto de Biologia, Universidade Federal do Rio de Janeiro. Avenida Carlos Chagas Filho 373, Bloco A, Cidade Universitária, 21941-902 Rio de Janeiro, Rio de Janeiro, Brasil.
\end{abstract}

\begin{abstract}
Liolaemus lutzae Mertens, 1938 is a critically endangered lizard endemic to the restinga habitat of the state of Rio de Janeiro. We surveyed 25 restinga habitats in order to locate remaining populations, evaluate the status of the species, and determine the nature of local habitat degradation. We found remnant populations of $L$. lutzae in 18 restinga habitats of six municipalities. The conservation status of each population varied between areas: the population of Grumari, in Rio de Janeiro municipality, is the most preserved and the population of Praia do Forte, in Cabo Frio, is the most disturbed. No L. lutzae were found in Niterói municipality. The most destructive type of habitat degradation identified was the removal of beach vegetation associated with the construction of coastal roads and/or sidewalks, destruction of the vegetation due to trampling, vehicle traffic and garbage dumping. Our data revealed that generally, beach habitats under a larger number of impact sources were those with smaller population sizes of L. lutzae. We consider that the most effective conservation measure for L. lutzae is the strict protection of its habitat, with restoration of the original beach vegetation. Finally, we recommend vegetation recovery to be followed by a program of reintroduction of the species in localities where it has been eradicated.
\end{abstract}

KEY WORDS. Conservation; endangered species; endemic species; habitat degradation; population recovery.

Of the 127 reptile species currently known to occur in the state of Rio de Janeiro, the sand lizard Liolaemus lutzae Mertens, 1938 is one of five species endemic to the state (the others are the teiid lizard Cnemidophorus littoralis, the snakes Pseudoboa serrana and Liotyphlops guentheri, and the aphisbaenid Leposternon scutigerum) (Rocha et al. 2000, 2004). Liolaemus lutzae is a small lizard (ca. 60-80 mm snout-vent length, when adult) that has a relatively small geographic distribution (ca. $200 \mathrm{~km}$ in extent) and is found from the Marambaia restinga in the west, to Cabo Frio municipality in the east (VANZOLIn \& AB'SABER 1968, RochA 1986). In the "restinga", an ecosystem of the Atlantic Rainforest biome comprising coastal sand dunes, the species is restricted to a thin strip (100 m wide maximum) of beach vegetation.

Most of the restinga found in the range of L. lutzae has been under intense anthropogenic disturbance, resulting in a considerable decrease in the total area of this type of habitat in the state of Rio de Janeiro (Rocha et al. 2003, 2005, 2007). This disturbance has led to the decline of several populations of $L$. lutzae (e.g. Rocha \& Bergallo 1992, Bergallo et al. 2000, Rocha et al. 2003) and has resulted in the species being included as "critically endangered" in the checklist of the threatened fauna of the state of Rio de Janeiro (Bergallo et al. 2000), in the Official List of Brazilian Fauna Threatened With Extinction (RocHA et al. 2008) and in the global checklist of IUCN Red List (RochA 2000a, IUCN 2007)

Despite the intense degradation occurring within the range of L. lutzae (Rocha \& Bergallo 1992, Rocha et al. 2003, 2007), there is currently only one study about the conservation status of the species (Rocha et al. 2009), which is restricted to a population of a single area, Barra da Tijuca, in the Rio de Janeiro municipality. Additionally, there is no information on the present geographic distribution and the local status of most populations of this endemic lizard throughout its range, which is fundamental to the implementation of strategies for the conservation of the species.

In the present study we surveyed 25 restinga areas along the $L$. lutzae distribution range in Rio de Janeiro State in order to locate remaining populations of the species, to evaluate the density of each remaining population, the potential threats to the species and the nature of local habitat degradation. We also estimated an index of population size in the different areas where the species still occurs. 


\section{MATERIAL AND METHODS}

The study was carried out in 25 beach habitats throughout the range of L. lutzae from Marambaia, in Rio de Janeiro municipality, to Peró beach in Cabo Frio municipality, the easternmost limit of the known distribution of the species (VANZOLINI \& Aв'S ABER 1968, Rocha 1986). The following areas were sampled: Marambaia, Grumari, Prainha, Macumba, Recreio dos Bandeirantes and Barra da Tijuca, in Rio de Janeiro municipality; Piratininga, Camboinhas, Itaipu and Itacoatiara, in Niterói municipality; Itaipuaçu, Barra de Maricá, Ponta Negra and Jaconé, in Maricá municipality; Barra Nova and Itaúna/ Jacarepiá, in Saquarema municipality; Massambaba and Figueiras in Araruama municipality; Pernambuca, Praia Grande and Praia dos Anjos, in Arraial do Cabo municipality; Praia do Foguete, Praia do Forte, Praia das Conchas and Praia do Peró, in Cabo Frio municipality (Fig 1). Restingas are salt-sandy strips located between the sea and the mountains of Brazil's eastern seaboard. This type of habitat originated in the Quaternary, resulting from successive marine regressions, which occurred throughout the Holocene and Pleistocene periods (MuEHe 1983, Perrin 1984, Suguio \& Tessler 1984). Liolaemus lutzae generally occurs within the strip of open sand up to $100 \mathrm{~m}$ wide, covered with herbaceous vegetation at the sea's edge (Rocha 1991).

We sampled each of the 25 areas for two consecutive years (2006 and 2007) in order to replicate the surveys and thus obtain a better estimate of the conservation status of each local population of L. lutzae. Our studies were usually carried out during the rainy season (October-March), the period when $L$. lutzae is reproductively active (Rocha 1992, 1998), to reduce the influence of possible differences in lizard abundance due to seasonality.

To evaluate the present distribution and to estimate the status of the populations of L. lutzae we standardized the total sampling effort to $360 \mathrm{~min}$ (180 $\mathrm{min} / \mathrm{year}$ ) in each locality. We sampled each restinga area one day per year. During sampling, we walked on a straight-line for about $2000 \mathrm{~m}$, moving at a regular walking pace, looking carefully for lizards in all microhabitats used by the species on the beach (RосHA 1991), and recording the number of lizards sighted. Samplings were always performed by walking in the same direction, with no transect overlapping another already sampled, in order to prevent double counting (individuals of L. lutzae are considerably resident; Rосна 1999). Lizards were sampled under similar weather conditions (sunny days), between 08:00 AM and 12:00 PM, a period that includes the peak of activity of L. lutzae (RochA 1998). To determine the conservation status of each population we calculated a standardized index of population density by dividing the total number of lizards sighted in a particular area by the total time (in minutes) spent in transects in that area (expressed as ind/min).

In addition, we recorded the following sources of disturbance on the beach habitat of each area studied: 1) removal of beach vegetation associated with the construction of coastal roads; 2) removal of beach vegetation associated with the construction of sidewalks; 3 ) trampling of the vegetation by people trying to gain access to the beach area; 4) occupation of beach habitat by residences; 5) presence of cars or motorcycles on sanddune vegetation; 6) removal of the beach vegetation during establishment of volleyball or football sand courts; 7) removal of the beach vegetation to place trade kiosks; 8) planting of exotic plant species such as grasses that replace the original vegetation 9) replacement of the original sand with another substrate unsuitable for L. lutzae along some portions of the habitat, as for example clay or gross sand;10) littering on the vegetation; 11) burning of vegetation in some portions of beach habitat to build fires for barbecue or for religious practices.

We compared the densities of L. lutzae between populations, through Analyses of Variance accomplished by Scheffe Post-hoc test (ZAR 1999). We tested the relationship between the estimated densities of L. lutzae, excluding the sites where the density was zero, and the number of disturbance sources for each locality using a Pearson Correlation Analysis.

\section{RESULTS AND DISCUSSION}

Remnant populations of L lutzae were present in 18 sampled areas located in six municipalities (Rio de Janeiro, Maricá, Saquarema, Araruama, Arraial do Cabo and Cabo Frio) in state of Rio de Janeiro (Tab. I and Fig. 1). Even though the four localities surveyed in Niterói (Piratininga, Camboinhas, Itaipu and Itacoatiara) had been previously listed in as being part of the geographic range of L. lutzae (VANZOLINI \& AB'SABER 1968, Rосна 1986), we failed to find representatives of the species in these areas.

The estimated index of population density varied significantly (ANOVA, $\mathrm{F}_{1,91}=7.68, \mathrm{p}<0.01$ ) across the areas where the species still occurs (Tab. I); these differences were observed on the populations of Grumari, Recreio, Barra Nova, Itaúna/ Jacarepiá, Ponta Negra, Praia do Forte, Conchas and Peró (Scheffe Post-hoc test, $\mathrm{p}<0.05)$. The areas with the highest estimated population densities were Grumari (0.80 ind/min), Barra da Tijuca (0.37 ind/min), Jaconé ( $0.31 \mathrm{ind} / \mathrm{min})$, Massambaba (0.27 ind/min) and Marambaia (0.23 ind/min). Given that the densities in these areas are relatively high, it seems reasonably safe to assume that these populations are at a lower risk of local extinction. Conversely, L. lutzae had the lowest estimated values of population densities in Praia do Forte (0.008 ind/min), Recreio dos Bandeirantes (0.03 in/min), Barra Nova (0.07 ind $/ \mathrm{min})$, Itaipuaçu (0.08 ind/min) and Praia das Conchas (0.08 ind/min) (Tab. I), indicating that the local populations are critically threatened. In some other areas, such as Praia Grande, Barra de Maricá and Praia do Foguete, we found intermediate population densities (index varying from 0.10 to $0.16 \mathrm{ind} / \mathrm{min}$; Tab. I).

Despite the moderate number of habitat degradation sources (six) present in the area, Grumari had the highest index of estimated density of L. lutzae (0.80 ind/min). The Grumari restinga, located within a conservation unit (APA de Grumari), 

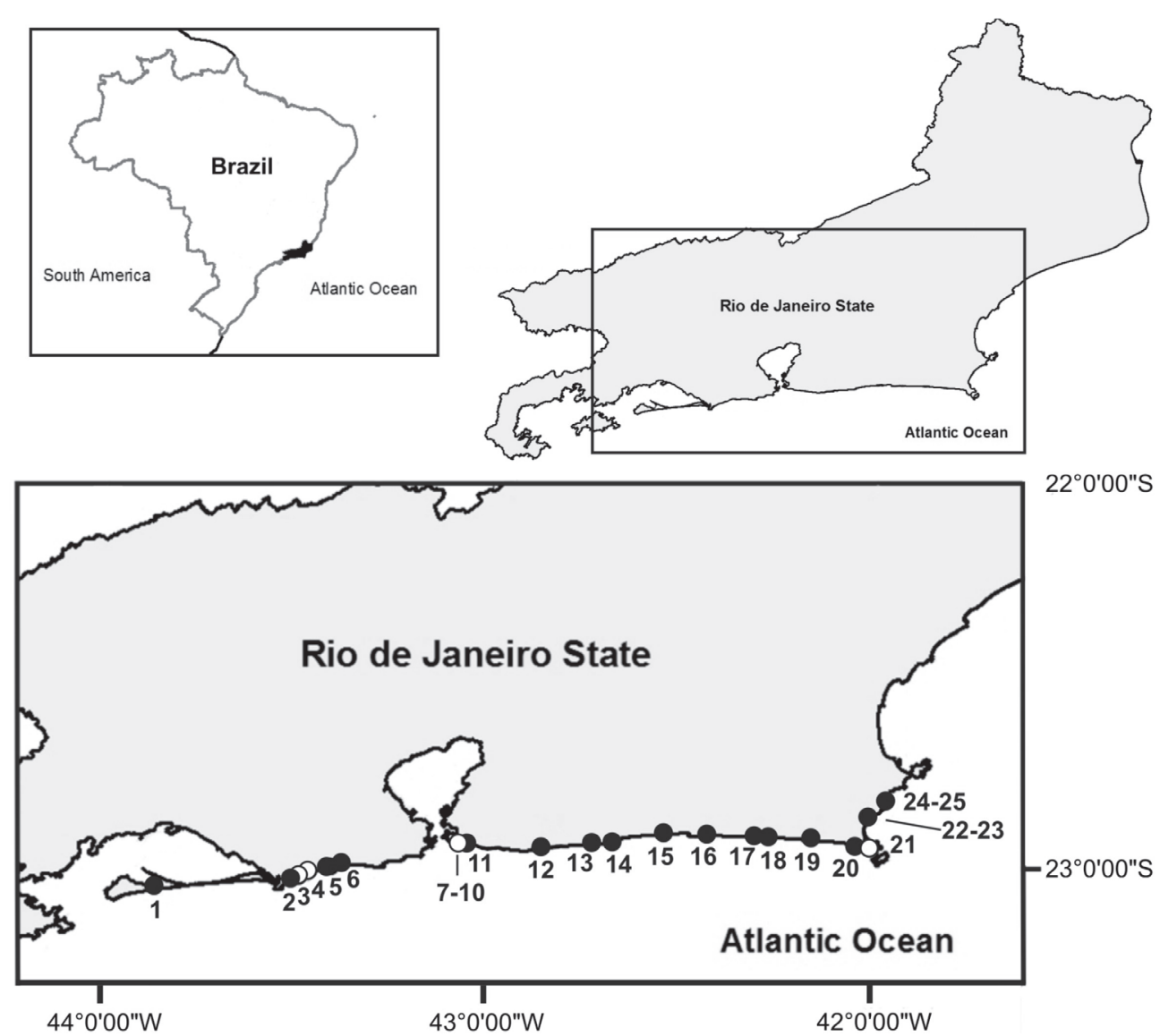

Figure 1. Current occurrence of $L$. lutzae along the State of Rio de Janeiro coast. Solid circles represent localities where the species currently occur and open circles localities where L. lutzae has been eradicated. The numbers on the map represent: 1) Marambaia, 2) Grumari, 3) Prainha, 4) Macumba, 5) Recreio, 6) Barra da Tijuca, 7-10) Piratininga, Camboinhas, Itaipu and Itacoatiara, 11) Itaipuaçu, 12) Barra de Maricá, 13) Ponta Negra, 14) Jaconé, 15) Barra Nova, 16) Itaúna/Jacarepiá, 17) Pernambuca, 18) Massambaba, 19) Figueiras, 20) Praia Grande, 21) Praia dos Anjos, 22-23) Praia do Foguete and Praia do Forte, 24-25) Praia das Conchas and Praia do Peró.

houses several human residences, including trading kiosks, and has a relatively low level of local vehicle traffic. Regardless of the high number of degradation sources in the area, however, it is still possible that anthropic impact is lower in Grumari relative to other areas sampled with a similar number of disturbance categories (Tab. I). This might in part explain the persistence of a dense local population of L. lutzae.

We did not find a significant relationship between the index of estimated density of L. lutzae and the number of impact sources (Pearson Correlation, $\mathrm{r}=0.392, \mathrm{p}>0.05, \mathrm{~N}=18$ ). However, when we excluded the population of Grumari (which represented an outlier) from the analyzes, we found a significant relationship (Pearson Correlation, $\mathrm{r}=0.548, \mathrm{p}<0.05, \mathrm{~N}=$ $17)$, which suggests a tendency for areas with high number of degradation sources to present lower population densities of $L$. lutzae (Fig. 2). Thus, the sources of disturbances on the beach habitat seem to have a negative impact on the lizards, mainly by reducing the beach vegetation area through alterations of the local plant composition and the original substrate. The native vegetation of the beach habitat is very important for the survival of L. lutzae, as a source of food (RocHA 1989, 1996, 2000b), shelter from predators (Rосна 1991, 1993), and protection from high environmental temperatures (Rосна 1995). Some species of lizards are known to be adversely affected mainly by both direct loss of habitat and by colonization by exotic species (e.g. Wilcove \& Chen 1998, Germano et al. 2001, Brooks et al. 2002, Germano \& Williams 2005). Habitat destruction is considered the main factor responsible for the population decline of endangered species, with colonization by exotic species coming as the second main factor (WILCOve \& CHEN 1998). Exotic plants such as grasses have been associated with a decline in abundance of some species of lizards severely contributing to the decline of their populations (BALLINGER \& WATTS 1995, Germano et al. 2001). 
Table I. Localities, coordinates, and Municipalities of some beach habitats where the local sand lizard population of $L$. lutzae was estimated; respective population density index for each site (expressed as individuals per minute) and disturbance sources recorded on each beach habitat.

\begin{tabular}{|c|c|c|c|c|}
\hline Localities & Municipality & Coordinates & Individuals/minute & Disturbance sources * \\
\hline Marambaia & Rio de Janeiro & $23^{\circ} 04^{\prime} 07^{\prime \prime} \mathrm{S}, 43^{\circ} 52^{\prime} 56^{\prime \prime} \mathrm{W}$ & 0.23 & 8,10 \\
\hline Grumari & Rio de Janeiro & $23^{\circ} 02^{\prime} 86^{\prime \prime} \mathrm{S}, 43^{\circ} 31^{\prime} 40^{\prime \prime} \mathrm{W}$ & 0.80 & $1,3,7,9,10,11$ \\
\hline Prainha & Rio de Janeiro & $23^{\circ} 02^{\prime} 36^{\prime \prime} \mathrm{S}, 43^{\circ} 30^{\prime} 18^{\prime \prime} \mathrm{W}$ & No L. lutzae & $1,3,7,8,9,10,11$ \\
\hline Macumba & Rio de Janeiro & $23^{\circ} 01^{\prime} 59^{\prime \prime} \mathrm{S}, 43^{\circ} 29^{\prime} 11^{\prime \prime} \mathrm{W}$ & No L. lutzae & $1,2,3,4,7,8,9,10,11$ \\
\hline Recreio & Rio de Janeiro & $23^{\circ} 00^{\prime} 87^{\prime \prime} \mathrm{S}, 43^{\circ} 23^{\prime} 82^{\prime \prime} \mathrm{W}$ & 0.03 & $1,2,3,6,7,8,9,10,11$ \\
\hline Barra da Tijuca & Rio de Janeiro & $23^{\circ} 00^{\prime} 93^{\prime \prime} \mathrm{S}, 43^{\circ} 24^{\prime} 82^{\prime \prime} \mathrm{W}$ & 0.37 & $1,8,10,11$ \\
\hline Piratininga & Niterói & $22^{\circ} 57^{\prime} 11^{\prime \prime} \mathrm{S}, 43^{\circ} 05^{\prime} 29^{\prime \prime} \mathrm{W}$ & No L. lutzae & $1,2,3,4,7,8,9,10,11$ \\
\hline Camboinhas & Niterói & $22^{\circ} 57^{\prime} 38^{\prime \prime} \mathrm{S}, 43^{\circ} 03^{\prime} 28^{\prime \prime} \mathrm{W}$ & No L. lutzae & $1,2,3,4,7,8,9,10,11$ \\
\hline Itaipu & Niterói & $22^{\circ} 58^{\prime} 10^{\prime \prime} \mathrm{S}, 43^{\circ} 02^{\prime} 58^{\prime \prime} \mathrm{W}$ & No L. lutzae & $1,2,3,4,5,6,7,8,9,10,11$ \\
\hline Itacoatiara & Niterói & $22^{\circ} 58^{\prime} 25^{\prime \prime} \mathrm{S}, 43^{\circ} 01^{\prime} 58^{\prime \prime} \mathrm{W}$ & No L. lutzae & $1,2,3,4,7,8,9,10,11$ \\
\hline Itaipuaçu & Maricá & $22^{\circ} 58^{\prime} 07^{\prime \prime} \mathrm{S}, 42^{\circ} 59^{\prime} 03^{\prime \prime} \mathrm{W}$ & 0.08 & $1,3,4,5,7,8,9,10$ \\
\hline Barra de Maricá & Maricá & $22^{\circ} 57^{\prime} 60^{\prime \prime} \mathrm{S}, 42^{\circ} 51^{\prime} 87^{\prime \prime} \mathrm{W}$ & 0.14 & $1,3,5,9,10,11$ \\
\hline Ponta Negra & Maricá & $22^{\circ} 57^{\prime} 01^{\prime \prime} \mathrm{S}, 42^{\circ} 43^{\prime} 07^{\prime \prime} \mathrm{W}$ & 0.12 & $1,2,3,4,6,7,8,9,10,11$ \\
\hline Jaconé & Maricá & $22^{\circ} 56^{\prime} 71^{\prime \prime} \mathrm{S}, 42^{\circ} 40^{\prime} 81^{\prime \prime} \mathrm{W}$ & 0.31 & $1,3,5,7,8,10,11$ \\
\hline Barra Nova & Saquarema & $22^{\circ} 55^{\prime} 91^{\prime \prime} \mathrm{S}, 42^{\circ} 33^{\prime} 24^{\prime \prime} \mathrm{W}$ & 0.07 & $1,2,3,4,6,7,8,9,10,11$ \\
\hline Itaúna/Jacarepiá & Saquarema & $22^{\circ} 55^{\prime} 99^{\prime \prime} \mathrm{S}, 42^{\circ} 25^{\prime} 95^{\prime \prime} \mathrm{W}$ & 0.10 & $1,2,3,4,5,6,7,8,9,10,11$ \\
\hline Pernambuca & Araruama & $22^{\circ} 56^{\prime} 27^{\prime \prime} \mathrm{S}, 42^{\circ} 19^{\prime} 00^{\prime \prime} \mathrm{W}$ & 0.10 & $1,3,4,5,7,8,9,10,11$ \\
\hline Massambaba & Araruama & $22^{\circ} 56^{\prime} 28^{\prime \prime} \mathrm{S}, 42^{\circ} 17^{\prime} 01^{\prime \prime} \mathrm{W}$ & 0.27 & $3,4,5,10$ \\
\hline Figueiras & Araruama & $22^{\circ} 56^{\prime} 40^{\prime \prime} \mathrm{S}, 42^{\circ} 10^{\prime} 21^{\prime \prime} \mathrm{W}$ & 0.16 & $1,3,4,5,6,7,8,9,10,11$ \\
\hline Praia Grande & Arraial do Cabo & $22^{\circ} 57^{\prime} 82^{\prime \prime} \mathrm{S}, 42^{\circ} 02^{\prime} 48^{\prime \prime} \mathrm{W}$ & 0.12 & $3,8,10$ \\
\hline Praia dos Anjos & Arraial do Cabo & $22^{\circ} 58^{\prime} 24^{\prime \prime} \mathrm{S}, 42^{\circ} 01^{\prime} 22^{\prime \prime} \mathrm{W}$ & No L. lutzae & $1,2,3,4,7,8,9,10$ \\
\hline Praia do Foguete & Cabo Frio & $22^{\circ} 56^{\prime} 17^{\prime \prime} \mathrm{S}, 42^{\circ} 02^{\prime} 22^{\prime \prime} \mathrm{W}$ & 0.11 & $1,2,3,4,5,6,8,9,10$ \\
\hline Praia do Forte & Cabo Frio & $22^{\circ} 53^{\prime} 26^{\prime \prime} \mathrm{S}, 42^{\circ} 01^{\prime} 32^{\prime \prime} \mathrm{W}$ & 0.008 & $1,2,3,5,6,7,8,9,10$ \\
\hline Praia das Conchas & Cabo Frio & $22^{\circ} 52^{\prime} 20^{\prime \prime} \mathrm{S}, 41^{\circ} 58^{\prime} 96^{\prime \prime} \mathrm{W}$ & 0.08 & $1,3,7,8,9,10$ \\
\hline Praia do Peró & Cabo Frio & $22^{\circ} 51^{\prime} 23^{\prime \prime} \mathrm{S}, 41^{\circ} 59^{\prime} 18^{\prime \prime} \mathrm{W}$ & 0.19 & $1,2,3,4,5,7,9,10,11$ \\
\hline
\end{tabular}

* Disturbance sources recorded on each beach habitat of L. lutzae: 1) removal of beach vegetation associated with the construction of coastal roads; 2) removal of beach vegetation associated with the construction of sidewalks; 3) trampling of the vegetation by people trying to gain access to the beach area; 4) occupation of beach habitat by residences; 5 ) presence of cars or motorcycles on sand-dune vegetation; 6) removal of the beach vegetation during establishment of volleyball or football sand courts; 7) removal of the beach vegetation to place trade kiosks; 8) planting of exotic plant species (e.g. grasses) that replace the original vegetation 9) replacement of the original sand with a different substrate unsuitable for $L$. lutzae along some portions of the habitat, as for example clay or gross sand; 10 ) littering on the vegetation; 11) burning of vegetation in some portions of beach habitat to build fires for barbecue or for religious practices.

In areas of beach habitat along the geographical range of L. lutzae, the most common sources of habitat degradation were, in general, the removal of beach vegetation associated with the construction of coastal roads and/or sidewalks, the trampling of vegetation by people trying to gain access to the beach area, the traffic of cars and/or motorcycles on the sand dune vegetation, and littering on vegetation (Tab. I). In some areas, such as Prainha and Praia da Macumba (in Rio de Janeiro municipality), Piratininga, Camboinhas, Itaipu, and Itacoatiara (in
Niterói), and Praia dos Anjos (in Arraial do Cabo), we observed that the strong habitat alteration associated with the construction of roads and sidewalks on the beach habitat resulted in extensive removal of the original vegetation. No individual of L. lutzae was found in those areas, in spite of the fact that the species was known to occur at least in Praia da Macumba, Prainha, Itacoatiara and Camboinhas (C.F.D. RocHA pers. obs). This suggests that the local populations of the species were eradicated from those areas, supposedly due to destruction of 


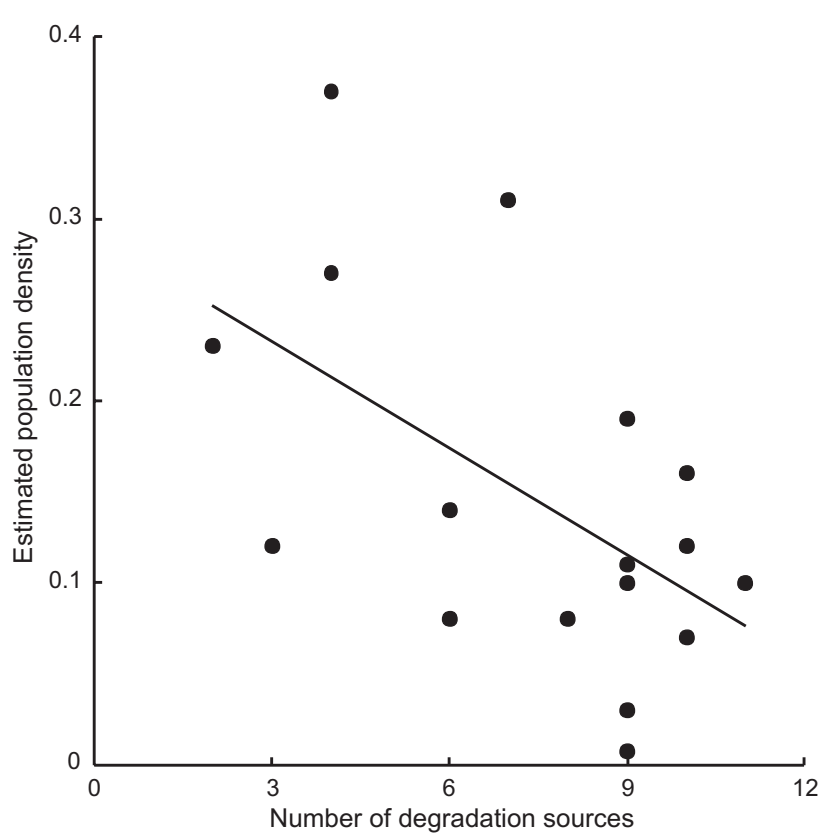

Figure 2. Relationship between estimated population density (expressed as individuals per minute) of L. lutzae and number of degradation sources in 17 localities along its geographic distribution in the State of Rio de Janeiro, Brazil.

the beach vegetation. A previous study measuring the decrease in population size of $L$. lutzae at a restinga area (Barra da Tijuca; Rocha \& Bergallo 1992) showed the negative effects of the destruction of the beach vegetation on the local population, promoting the decline of the lizard in the area.

Unfortunately, data on local density or population sizes for L. lutzae is still scarce (SoARes \& Araújo 2008, Rocha et al. 2009). An experimental introduction of L. lutzae was carried out in the state of Espírito Santo 18 years ago, to an area 200 $\mathrm{km}$ from the original population in Barra de Maricá, state of Rio de Janeiro, outside the original range of the species. Current data shows that the population successfully colonized the Praia das Neves beach (SoAres \& Araújo 2008). In Barra da Tijuca (adjacent to the type locality of L. lutzae - Recreio dos Bandeirantes), in Rio de Janeiro municipality, an estimate of the population size conducted in 1991 showed a considerable decrease (about 65\%) when compared to a previous estimate from 1984. This decline was attributed to anthropic disturbances that affected the beach vegetation locally (Rocha \& Bergallo 1992). The environmental disturbance continued until year 2000, when the Secretaria do Meio Ambiente (Environmental Bureau) of the municipality of Rio de Janeiro implemented a program for the environmental recovery of the area, starting year 2001. Population density estimates conducted in 2002 and 2006 showed an increase in the mean number of recorded individuals of L. lutzae (Rocha et al. 2009). Thus, as observed in Barra da Tijuca, the recovery of habitat quality in other areas along the range of $L$. lutzae can potentially have a positive impact on the local populations. The indices of population size provided by the present study not only allow comparisons on population status between areas but also can be useful for monitoring the numbers of $L$. lutzae in the near future in the different areas where it still survives.

\section{Management recommendations}

We consider that the easiest course of action to protect the remaining populations of $L$. lutzae is the strict protection of its habitat in the localities where the species still occurs and the implementation of habitat recovering programs with native plant species that are part of the original habitat (RocHA 1991) and diet (Rocha 1989, 2000b) of L. lutzae. Also, we strongly recommend the reintroduction of the species in the localities from which it has been eradicated, following a suitable habitat recovery program. Some areas that are relatively small and somewhat isolated from other beach habitats, such as Prainha and Praia da Macumba, in Rio de Janeiro municipality, are excellent candidates to use as study cases for habitat recovery and reintroduction planning for L. lutzae.

Considering that many restinga areas where this lizard occurs with small population sizes (e.g. Recreio dos Bandeirantes, Itaipuaçu, Barra Nova, Praia do Forte and Praia das Conchas) are currently under strong habitat destruction pressures, urgent conservation actions should be carried out to protect the beach vegetation. If action is not taken, L. lutzae populations may continue to decline in those areas what may result in local extinction in the near future. The disappearance of $L$. lutzae from beach habitats in Niterói municipality highlights the need for conservation programs implemented by local government agencies that seek to restore suitable habitat conditions, which should precede an eventual program for the reintroduction of L. lutzae in those areas.

\section{ACKNOWLEDGEMENTS}

This study was developed as part of Edital Espécies Ameaçadas of Fundação Biodiversitas/CEPAN (Project 078H/022004). CFDR also benefited from research grants from the Conselho Nacional do Desenvolvimento Científico e Tecnológico - CNPq (307653/03-0 and 476684/2008-8) and from Fundação Carlos Chagas Filho de Amparo à Pesquisa do Estado do Rio de Janeiro - FAPERJ (E-26/100.471/2007) through Programa Cientistas do Nosso Estado. During this study CCS and CVA received a graduate fellowship from FAPERJ. Currently CCS is associated to the Programa de Pós-Graduação em Ecologia, Universidade Federal do Rio de Janeiro, and receives a PhD grant from CNPq. We thank the local office of Ministry of Aeronautics for permission to conduct studies in Marambaia, and Davor Vrcibradic, Leonardo Gamarra, and Ana Cristina Martins for field assistance. We are also grateful to Andrea F. Oliveira and Gisele R. Winck for the map. We thank Davor Vrcibradic and Robert Pickles who kindly revised the manuscript offering helpful suggestions. The Instituto Biomas provided some logistic support for this study. 


\section{LITERATURE CITED}

BALlinger, R.R. \& K.S. WATTS. 1995. Path to extinction: impact of vegetation change on lizard populations on rapaho prairie in the Nebraska sandhill. American Midland Naturalist 134: 413-417.

Bergallo, H.G.; C.F.D. Rocha; M.A.S. Alves \& M. Van Sluys. 2000. A fauna ameaçada de extinção do Estado do Rio de Janeiro. Rio de Janeiro, Editora Universidade do Estado do Rio de Janeiro, 166p.

Brooks, T.M.; R.A. Mittermeier; C.G. Mittermeier; G.A.B. Fonseca; A.B. Rylands; W.R. Konstant; P. Flick \& C. Hilton-Taylor. 2002. Habitat loss and extinction in the hotspots of biodiversity. Conservation Biology 16 (4): 909-923.

Germano, D. J. \& D.F. Williams. 2005. Population ecology of bluntnosed leopard lizards in high elevation foothill habitats. Journal of Herpetology 39 (1): 1-18.

Germano, D. J.; G.B. Rathbun \& L.R. SASLAW. 2001. Managing exotic grasses and conserving declining species. Wildlife Society Bulletin 29 (2): 551-559.

IUCN. 2007. IUCN Red List of Threatened Species. 2007. International Union for Conservation of Nature and Natural Resources. Available online at: http://www.iucnredlist.org [Accessed: 17/VI/2008]

Muene, D. 1983. Conseqüências higroclimáticas das glaciações quartenárias no relevo costeiro a leste da Baía de Guanabara. Revista Brasileira de Geociências 13: 245-252.

Perrin, P. 1984. Evolução da costa fluminense entre as pontas de Itacoatiara e negra: Preenchimentos e restingas, p. 65-74. In: L.D. Lacerda; D.S.D. Araújo; R. Cerqueira \& B. Turce (Eds). Restingas: origem, estrutura, processos. Niterói, CEUFF, $477 \mathrm{p}$.

Rocha, C.F.D. 1986. Distribuição geográfica de Liolaemus lutzae: um lagarto endêmico do Estado do Rio de Janeiro. Boletim da Fundação Brasileira para a Conservação da Natureza 20: $163-167$.

RochA, C.F.D. 1989. Diet of a tropical lizard (Liolaemus lutzae) of southeastern Brazil. Journal of Herpetology 23: 292-294.

Rocha, C.F.D. 1991. Composição do habitat e uso do espaço por Liolaemus lutzae (Sauria: Iguanidae) em uma area de restinga. Revista Brasileira de Biologia 51 (4): 839-845.

Rосна, C.F.D. 1992. Reproductive and fat body cycles of the tropical sand Lizard (Liolaemus lutzae) of Southeastern Brazil. Journal of Herpetology 26 (1): 17-23.

Rocha, C.F.D. 1993. The set of defense mechanisms in the tropical lizard Liolaemus lutzae of Southeastern Brazil. Ciência e Cultura 45 (2): 116-122.

Rocha, C.F.D. 1995. Ecologia termal de Liolaemus lutzae (Sauria: Tropiduridae) em uma área de Restinga do Sudeste do Brasil. Revista Brasileira de Biologia 55 (3): 481-489.

Rосна, C.F.D. 1996. Seasonal shift in lizard diet: the seasonality in food resources affecting the diet of Liolaemus lutzae (Tropiduridae). Ciência e Cultura 48 (4): 264-270.
Rocha, C.F.D. 1998. Population dynamics of the endemic tropidurid lizard Liolaemus lutzae in a tropical seasonal restinga habitat. Ciência e Cultura 50 (6): 446-451.

RochA, C.F.D. 1999. Home range of the tropidurid lizard Liolaemus lutzae: sexual and body size differences. Revista Brasileira de Biologia 59 (1): 125-130.

RocHA, C.F.D. 2000a. Liolaemus lutzae. In: IUCN 2007. IUCN Red List of Threatened Species. Available online at: http:// www.iucnredlist.org [Accessed: 18/IX/2008]

RocHA, C.F.D. 2000b. Selectivity in plant food consumption in the lizard Liolaemus lutzae from Southeastern Brazil. Studies on Neotropical Fauna Environment 35: 14-18.

Rocha, C.F.D. \& H.G. Bergallo. 1992. Population Decrease: the case of Liolaemus lutzae, an endemic lizard of Southeastern Brazil. Ciência e Cultura 44 (1): 52-54.

Rocha, C.F.D.; M. Van Sluys; G. Puorto; R. Fernandes; J.D. Barros-Filho; R. Rocha e Silva; F.A. Néo \& A. Melgarejo. 2000. Répteis, p. 79-166. In: H.G. Bergallo; C.F.D. Rocha; M.A.S. AlVES \& M. VAN SLuYs (Eds). A fauna ameaçada de extinção do Estado do Rio de Janeiro. Rio de Janeiro, Universidade do Estado do Rio de Janeiro, 166p.

Rocha, C.F.D.; M.A.S. Alves \& M. Van Sluys. 2003. A biodiversidade nos grandes remanescentes florestais do Rio de Janeiro e nas restingas da Mata Atlântica. São Carlos, Rima Editora, 160p.

Rocha, C.F.D; H.G. Bergallo; J.P. Pombal Jr; L. Geise; M. Van Sluys; R. Fernandes \& U. Caramaschi. 2004. Fauna de anfíbios, répteis e mamíferos do estado do Rio de Janeiro, sudeste do Brasil. Publicações Avulsas do Museu Nacional 104: 3-23. Rocha, C.F.D.; M. Van Sluys; H.G. Bergallo \& M.A.S. Alves. 2005. Endemic and threatened tetrapods in the Restingas of the biodiversity corridors of Serra do Mar and of the Central da Mata Atlântica in eastern Brazil. Brazilian Journal of Biology 65 (1): 159-168.

Rocha, C.F.D.; H.G. Bergallo; M. Van Sluys; M.A.S. Alves \& C. JAMEL. 2007. The remnants of restinga habitats in the Brazilian Atlantic Forest of Rio de Janeiro State, Brazil: habitat loss and risk of disappearance. Brazilian Journal of Biology 67 (2): 263-273.

Rocha, C.F.D.; C.V. Ariani \& C.C. SiqueIra. 2008. Liolaemus lutzae Mertens, 1938, p. 345-347. In: A.B. M. Machado; G.M. Drummont \& A.P. Paglia (Eds). Livro Vermelho da Fauna Brasileira Ameaçada de Extinção. Belo Horizonte, Fundação Biodiversitas, 906p.

Rocha, C.F.D.; C.C. Siqueira \& C.V. Ariani. 2009. The recovery of a population of the sand lizard Liolaemus lutzae in an area within its range: a lizard endemic and threatened with extinction. Brazilian Journal of Biology 69 (1): 185-187.

SoARES, A.H.B. \& A.F.B. ARAúJo. 2008. Experimental introduction of Liolaemus lutzae (Squamata, Iguanidae) in Praia das Neves, State of Espírito Santo, Brazil: a descriptive study 18 years later. Revista Brazileira de Zoologia 25 (4): 640-646. Suguio, K. \& M.G. Tessler. 1984. Planícies de cordões litorâneos 
quaternários do Brasil: origem e nomenclatura, p. 15-25. In: L.D. Lacerda; D.S.D. Araújo; R. Cerqueira \& B. Turce (Eds). Restingas, Origem, Estrutura e Processos. Niterói, Anais do Simpósio sobre Restingas Brasileiras, Centro Editorial da Universidade Federal Fluminense, 477p.

VAnZolini, P.E. \& A.N. Aв'SABER. 1968. Divergence rate in South
American lizards of the genus Liolaemus (Sauria, iguanidae). Papéis Avulsos de Zoologia 21: 205-208.

Wilcove, D.S. \& L.Y. Chen. 1998. Management costs for endangered species. Conservation Biology 12 (6): 1405-1407.

ZAR, J. 1999. Biostatistical analysis. New Jersey, Prentice Hall, 929.

Submitted: 20.XI.2008; Accepted: 13.IX.2009.

Editorial responsibility: Fernando de Camargo Passos 